\title{
“ANALYSIS AND DESIGN OF MULTI-STOREYED LOAD BEARING REINFORCED MASONRY STRUCTURE AND FRAMED RC STRUCTURE"
}

\author{
Shashank B.S ${ }^{1}$, S.Raghunath ${ }^{2}$ \\ ${ }^{1}$ Assistant Professor, Civil Engineering, TOCE, shashankbsbhat.bs@gmail.com, Karnataka, India \\ ${ }^{2}$ Professor, Civil Engineering, BMSCE, raghunath.smrc@gmail.com, Karnataka, India
}

\begin{abstract}
Load bearing masonry structures in India are generally restricted to 3 or 4 storeys in height. This is mainly because of lack of availability of good quality masonry unit and associated workmanship. Also, it is generally perceived that load bearing masonry storey may perform in brittle manner under excessive lateral loads. However, with the advancement of availability of engineered hollow concrete blocks which has a scope to introduce reinforcement, it is perhaps possible to design and eventually construct multistoreyed reinforced masonry building. In this paper an attempt has been made to analyse and design the structural components of a multi-storeyed residential building using reinforced hollow concrete block masonry. (i) Residential occupancy in ground floor +8 floors. The building is analysed and designed for all the load combination as per the codal provisions. Later the same building is analysed and design by considering it as conventional RC framed structure system. The structural comparison of both of them has been made. Based on the study it is found that the requirement of reinforcing steel and concrete is significantly lesser, when compared to building designed as load bearing masonry system. It is also found that masonry prism strength of 7.5MPa with nominal vertical reinforcement is adequate to withstand the combination of axial and lateral loads.
\end{abstract}

Keywords: Load bearing, hollow block, Reinforcement, Lateral strength, RC Frame $* * *$

\section{INTRODUCTION}

There are a lot of arguments about the actuality of reinforced masonry. Although bricks belong to the conventional and traditional building materials, reinforced concrete frames are favored in construction industry nowadays. In that case the masonry is used purely as an infill wall. The load bearing capacity of masonry is only significant for the design of some storey constructions. On the other hand, it is possible to dispense with RC frame and construct multi storied load bearing masonry structures, when good quality blocks are used in conjunction with reinforcement.

\subsection{Reinforced Masonry}

In India there has not been much progress in the construction of tall load bearing masonry structures, mainly because of poor quality of masonry workmanship and material such as clay bricks that are manufactured even today having nominal strength of only 7.0 to $10.0 \mathrm{MPa}$. However recently mechanized brick plants are producing brick units of strength 17.5 to $24 \mathrm{MPa}$ and therefore it is possible to construct 5 to 6 storied load bearing structures at costs less than those of RC framed structures.

Reinforced masonry (RM) is more economical and structurally efficient than framed $\mathrm{RC}$ structure (a) If good quality blocks are produced

(b) If reinforcement is suitably introduced

(c) If the strength and elastic properties are known

In load bearing walls, when the plan length of openings exceeds approximately one- half the total plan length of the wall and lateral forces act on the walls whether in- plane or out of plane, flexural tensile stresses generally become so large that the walls must be designed as reinforced. Reinforcement can also be used to increase shear resistance.

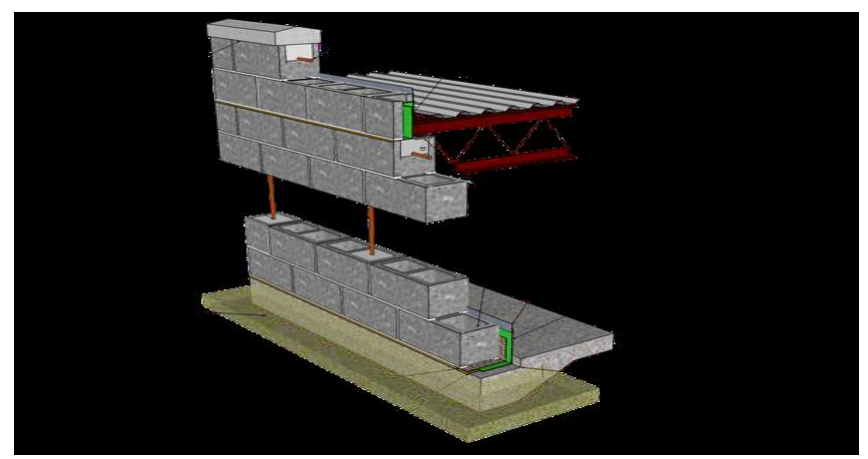

Fig-1 Reinforced masonry 


\section{STRUCTURAL DESIGN OF REINFORCED}

\section{MASONRY}

Permissible Compressive Force: Compressive force in reinforced masonry due to axial load shall not exceed that given by following equation:

$$
P o=\left(0.25 f_{m}{ }^{\prime} A_{n}+0.65 A_{s t} F_{S}\right) K_{s}
$$

Where,

$\mathrm{A}_{\mathrm{n}}=$ Net area

$\mathrm{A}_{\mathrm{st}}=$ Area of steel

$\mathrm{F}_{\mathrm{s}}=$ Permissible steel tensile stress

$\mathrm{K}_{\mathrm{s}}=$ Stress reduction factor as in Table 9 of IS: $1905-1987$

The compressive force at the section from axial loads or from the axial component of combined loads is calculated separately as is limited to the permissible values. A coefficient of 0.25 provides a factor of safety of about 4.0 against crushing of masonry. The coefficient of 0.65 was determined from tests on masonry.

Permissible Shear Stress for Reinforced masonry members

a) For Flexural members

i). Without Web Reinforcement

$\mathrm{F}_{\mathrm{v}}=0.083 \mathrm{f}_{\mathrm{m}}$ but not greater than $0.25 \mathrm{MPa}$

ii). With Web Reinforcement

$\mathrm{F}_{\mathrm{v}}=0.25 \mathrm{f}_{\mathrm{m}}$ but not greater than $0.75 \mathrm{MPa}$

\section{b) For Walls}

For reinforced masonry, the shear resistance is offered by both masonry and reinforcement, however, their effect is not taken additive in this document, like many other masonry codes. This has basis in an experimental research by Priestley and Bridgeman which concluded that the shear reinforcement in masonry is effective in providing resistance when it is designed to carry the full shear load. If calculated shear stress exceeds the allowable shear stress for masonry, full shear load has to be resisted by the reinforcement alone which is placed parallel to the applied shear force direction. The amount of shear reinforcement. Experiments have shown that shear resistance of the reinforced shear walls are function of the aspect ratio of the wall (i.e., ratio of height to length), besides distribution of reinforcement and masonry strength. Shear walls with lower aspect ratio have been provided with higher allowable shear stress.

\section{LOAD BEARING MASONRY ELEMENT-CASE}

\section{STUDY}

The major objective of this Paper is to demonstrate a comprehensive design procedure for multi-storied load bearing masonry building. Typical residential building with identical floor plans is amenable to be design as load bearing structure. Avoiding provision of walls out of line with walls in the underneath floors is crucial. Such a layout will ensure the avoidance of beam. As a consequence of which excessive point loads on load bearing walls can be avoided.

At this juncture that it is crucial to identify the load bearing elements. Here it is provident to avoid considering walls of significantly small cross section area as load bearing element in this case study is identified with wall A to $Z$ and A' to K' for axial load analysis and for the lateral load analysis it is identified as 1 t0 54.It can be noticed that the walls for bath room kitchens (which are lesser than $200 \mathrm{~mm}$ thickness) is not considered as load bearing masonry walls.

The process of design as already mentioned is carried out in 3 phases, viz,

a) Calculation of loads

b) Design for axial and eccentric loads

c) Design for flexure and shear

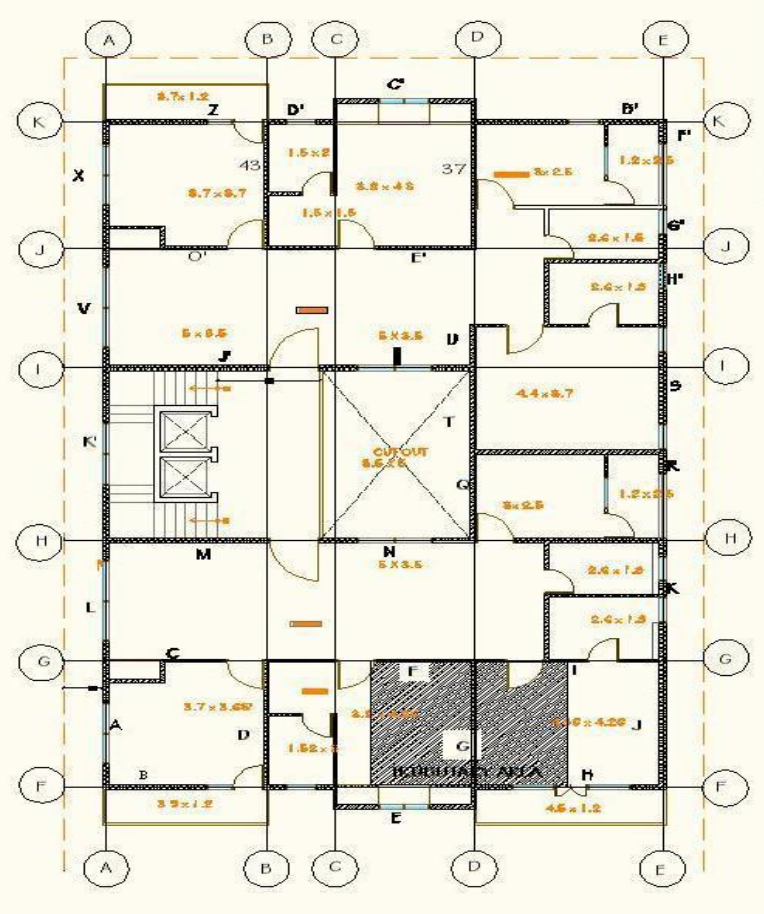

Fig -2: Plan of 1st Floor

\subsection{Design of Wall Element Axial/Eccentric Loads}

A building is basically subjected to two types of loads, namely: a) Vertical loads on account of dead loads of materials used in construction, plus live loads due to occupancy; and b) Lateral loads due to wind and seismic forces. While all walls in general can take vertical loads, ability of a wall to take lateral loads depends on its disposition in relation to the direction of lateral load. In general a structural wall shall be designed to with stand axial 
compression, stress due to eccentricity in plane shear and out of plane building.

\subsubsection{Design Loads}

Loads to be taken into consideration for designing masonry components of a structure are: a) Dead loads of walls, columns, floors and roofs; b) Live loads of floors and roof c) Wind loads on walls d) Seismic forces.

1. Dead loads shall be calculated on the basis of unit weights taken in accordance with IS: 875-1 (1987).

2. Live loads of floors and roof shall be calculated on the basis of unit weights taken in accordance with IS: 875-2 (1987).

3. Wind loads on walls calculated on the basis of IS: $875-3$ (1987).

4. Seismic forces on walls is calculated by using IS 1893-2002 part 1.

Table -1: Sample Stress Calculation

\begin{tabular}{|c|c|c|c|c|c|c|c|c|}
\hline $\begin{array}{l}\text { W } \\
\text { al } \\
\text { ls }\end{array}$ & $\mathrm{L}$ & $\mathrm{L}_{\mathrm{eff}}$ & SR & $\begin{array}{l}\text { Net } \\
\text { area } \\
\mathrm{mm}^{2}\end{array}$ & $\begin{array}{l}\text { Loa } \\
\text { d kn }\end{array}$ & $\begin{array}{c}\text { Stress } \\
\text { Devel } \\
\text { oped } \\
\text { MPa }\end{array}$ & $\begin{array}{l}\text { Stres } \\
\mathrm{s} \\
\text { allow } \\
\text { able } \\
\mathrm{MPa}\end{array}$ & $\begin{array}{l}\mathrm{Fac} \\
\text { tor }\end{array}$ \\
\hline A & $\begin{array}{c}3.6 \\
5\end{array}$ & $\begin{array}{c}2.9 \\
7\end{array}$ & $\begin{array}{c}11 . \\
2\end{array}$ & 72817 & $\begin{array}{c}657 . \\
1\end{array}$ & 0.902 & 2.250 & $\begin{array}{c}2.4 \\
9\end{array}$ \\
\hline B & $\begin{array}{c}3.7 \\
4 \\
\end{array}$ & $\begin{array}{c}1.8 \\
4 \\
\end{array}$ & $\begin{array}{c}9.2 \\
4 \\
\end{array}$ & 74662 & $\begin{array}{c}997 . \\
8\end{array}$ & 1.337 & 2.644 & $\begin{array}{c}1.9 \\
8\end{array}$ \\
\hline C & $\begin{array}{c}3.7 \\
5\end{array}$ & $\begin{array}{c}1.8 \\
4\end{array}$ & $\begin{array}{c}9.2 \\
4\end{array}$ & 74916 & $\begin{array}{c}107 \\
6 .\end{array}$ & 1.437 & 2.644 & $\begin{array}{l}1.8 \\
40\end{array}$ \\
\hline D & $\begin{array}{c}4.1 \\
4\end{array}$ & $\begin{array}{c}3.8 \\
1\end{array}$ & $\begin{array}{c}11 . \\
2\end{array}$ & 82800 & $\begin{array}{c}134 \\
6 .\end{array}$ & 1.626 & 2.250 & $\begin{array}{c}1.3 \\
8\end{array}$ \\
\hline E & 4.7 & $\begin{array}{c}4.3 \\
9\end{array}$ & $\begin{array}{c}11 . \\
2\end{array}$ & 93878 & 877 & 0.935 & 2.250 & $\begin{array}{c}2.4 \\
0\end{array}$ \\
\hline $\mathrm{F}$ & $\begin{array}{c}3.2 \\
7\end{array}$ & $\begin{array}{c}3.8 \\
1\end{array}$ & $\begin{array}{c}11 . \\
2\end{array}$ & $\begin{array}{c}65316 \\
1\end{array}$ & 991 & 1.517 & 2.250 & $\begin{array}{c}1.4 \\
8\end{array}$ \\
\hline G & 4.1 & $\begin{array}{c}3.4 \\
0\end{array}$ & $\begin{array}{c}11 . \\
2\end{array}$ & $\begin{array}{c}82000 \\
0\end{array}$ & $\begin{array}{c}142 \\
9\end{array}$ & 1.743 & 2.250 & $\begin{array}{c}1.2 \\
9\end{array}$ \\
\hline
\end{tabular}

\subsection{Lateral Load Analysis and Design}

A building is basically subjected to two types of loads, namely: 1. vertical loads on account of dead loads of materials used in construction, plus live loads due to occupancy; and 2. Lateral loads due to wind and seismic forces. Lateral loads from the wind or earthquakes are generally considered to act in the direction of the principal axes of the building structure. The distribution of lateral loads to various masonry wall elements depends on the rigidities of the horizontal floor or roof diaphragm and of the wall elements. If a diaphragm does not undergo significant in-plane deformation with respect to the supporting walls, it can be considered rigid and lateral loads are distributed in various lateral load resisting wall elements in proportion to their relative stiffness.

\subsubsection{Distribution of Lateral Forces in the Piers of a}

\section{Masonry Wall}

Masonry walls are often seen to be perforated to make arrangement for windows and doors. The distribution of lateral force in a masonry wall is dependent on the position of the openings and the relative rigidity of the masonry piers created due to the presence of the openings in the masonry wall. The relative rigidity is dependent on the height by length ratio $(\mathrm{h} / \mathrm{L}$ Ratio) of the piers and the end conditions of those masonry piers as the deflection of the masonry piers due to horizontal loading changes due to the end condition of the piers. Here a simple process is described which can be used to distribute the lateral force in a wall which can be considered to be consist of some piers with some specific arrangements.

In any kind of placing of opening the wall can be represented as a horizontal and vertical combination of piers with their respective end condition which will be used to find out their rigidities. Where large openings occur, it is difficult to obtain effective coupling of the wall segments or piers.

Lateral loads shall be distributed to the structure system in accordance with member stiffness for rigid diaphragms or tributary areas for flexible diaphragms and shall comply with the following requirements 1 . Flanges of intersecting walls designed in accordance to IS 1905 draft section 4.2.2.5 shall be included in stiffness determination. 2. Distribution of load shall include the effect of diaphragm rigidity and of horizontal torsion due to eccentricity of wind and seismic loads resulting from non-uniform distribution of mass

\subsubsection{Wind Load Analysis}

The wind force calculated from these factors is assumed to act as an equivalent uniformly distributed load on the building for its full height. sometimes the wind velocity or the gust factor is assumed variable with the height of the building ,so that the intensity of the equivalent uniformly distributed load varies accordingly in the united kingdom wind loads on buildings are calculated from the provisions of the code of practice CP3 chapter V Part 21970 whilst masonry is strong in compression it is very weak in tension thus engineering design for wind loading may be needed not only for multi storey structures but also for some single storey structures

Design Wind Speed $\left(\mathrm{V}_{\mathrm{z}}\right)$ The basic wind speed $\left(\mathrm{V}_{\mathrm{z}}\right)$ for any site shall be obtained from and shall be modified to include the following effects to get design wind velocity at any height $\left(\mathrm{V}_{\mathrm{z}}\right)$ for the chosen structure:

a) Risk level; b) Terrain roughness, height and size of structure; and c) Local topography. d) It can be mathematically expressed as follows: $\mathrm{V}_{\mathrm{z}}=\mathrm{V}_{\mathrm{b}} \mathrm{k}_{1} \quad \mathrm{k}_{2} \quad \mathrm{k}_{3} \mathrm{~V}_{\mathrm{b}}=$ design wind speed at any height $\mathrm{z}$ in $\mathrm{m} / \mathrm{s} ; \mathrm{k}_{1}=$ probability factor (risk coefficient) $k_{2}=$ terrain, height and structure size factor and $\mathrm{k}_{3}=$ topography factor 
Table -2: Wind load

\begin{tabular}{|c|c|c|c|c|c|c|c|c|c|}
\hline $\begin{array}{l}\text { Flo } \\
\text { or }\end{array}$ & $\begin{array}{l}\text { Heigh } \\
\mathbf{t} \\
\mathbf{M}\end{array}$ & $\begin{array}{l}\mathbf{V} \\
\mathbf{b} \\
\mathbf{m} \\
/ \mathbf{s}\end{array}$ & $\mathbf{k}_{1}$ & $\mathbf{k}_{2}$ & $\mathbf{k}$ & $\begin{array}{l}\mathbf{V}_{\mathrm{Z}} \\
\mathrm{N} / \mathrm{m}\end{array}$ & $\begin{array}{l}\text { AR } \\
\text { EA } \\
\mathbf{m}^{2}\end{array}$ & $\begin{array}{l}\mathbf{P}_{\mathbf{z}} \\
\mathbf{k N}\end{array}$ & $\begin{array}{l}\text { kN } \\
\text { Wi } \\
\text { nd } \\
\text { for } \\
\text { ce }\end{array}$ \\
\hline 1 & 3 & $\begin{array}{l}5 \\
5\end{array}$ & $\begin{array}{l}1.0 \\
5\end{array}$ & $\begin{array}{l}0.8 \\
8\end{array}$ & 1 & $\begin{array}{l}50.8 \\
20\end{array}$ & 60 & $\begin{array}{l}154 \\
9\end{array}$ & 111 \\
\hline 2 & 6 & $\begin{array}{l}5 \\
5\end{array}$ & $\begin{array}{l}1.0 \\
5\end{array}$ & $\begin{array}{l}0.8 \\
8\end{array}$ & 1 & $\begin{array}{l}50.8 \\
20\end{array}$ & 60 & $\begin{array}{l}154 \\
9\end{array}$ & 111 \\
\hline 3 & 9 & $\begin{array}{l}5 \\
5\end{array}$ & $\begin{array}{l}1.0 \\
5\end{array}$ & $\begin{array}{l}0.8 \\
8\end{array}$ & 1 & $\begin{array}{l}50.8 \\
20\end{array}$ & 60 & $\begin{array}{l}154 \\
9\end{array}$ & 111 \\
\hline 4 & 12 & $\begin{array}{l}5 \\
5\end{array}$ & $\begin{array}{l}1.0 \\
5\end{array}$ & $\begin{array}{l}0.9 \\
4\end{array}$ & 1 & $\begin{array}{l}54.2 \\
85\end{array}$ & 60 & $\begin{array}{l}176 \\
8\end{array}$ & 127 \\
\hline 5 & 15 & $\begin{array}{l}5 \\
5\end{array}$ & $\begin{array}{l}1.0 \\
5\end{array}$ & $\begin{array}{l}0.9 \\
6\end{array}$ & 1 & $\begin{array}{l}55.4 \\
40\end{array}$ & 60 & $\begin{array}{l}184 \\
4\end{array}$ & 132 \\
\hline 6 & 18 & $\begin{array}{l}5 \\
5\end{array}$ & $\begin{array}{l}1.0 \\
5\end{array}$ & $\begin{array}{l}0.9 \\
8\end{array}$ & 1 & $\begin{array}{l}56.5 \\
95\end{array}$ & 60 & $\begin{array}{l}192 \\
1\end{array}$ & 138 \\
\hline 7 & 21 & $\begin{array}{l}5 \\
5 \\
\end{array}$ & $\begin{array}{l}1.0 \\
5\end{array}$ & 1.0 & 1 & $\begin{array}{l}57.7 \\
50 \\
\end{array}$ & 60 & $\begin{array}{l}200 \\
1 \\
\end{array}$ & 144 \\
\hline 8 & 24 & $\begin{array}{l}5 \\
5\end{array}$ & $\begin{array}{l}1.0 \\
5\end{array}$ & $\begin{array}{l}1.0 \\
9\end{array}$ & 1 & $\begin{array}{l}62.9 \\
48 \\
\end{array}$ & 60 & $\begin{array}{l}237 \\
7\end{array}$ & 171 \\
\hline
\end{tabular}

Total force $=1048 \mathrm{kN}$.

\subsubsection{Sesmic Load Analysis}

The primary objective of earthquake resistant design is to prevent building collapse during earthquakes thus minimizing the risk of death or injury to people in or around those buildings. Because damaging earthquakes are rare, economics dictate that damage to buildings is expected and acceptable provided collapse is avoided.

Earthquake Resistant Design-The following steps may be taken:

(a) Estimate fundamental time period Ta using empirical expressions given in the Code IS: 1893-10 2002.

(b) Calculate the design horizontal Seismic coefficient Ah

The design horizontal coefficient $\mathrm{Ah}$ is given by

$$
\mathrm{A}_{\mathrm{h}}=\frac{Z I}{2 R} \frac{S a}{g}
$$

Take Z for the applicable seismic zone (IS: 1893 Cl.6.4.2), Take I for the use importance of the building (IS: 1893 Table 2),

Take $\mathrm{R}$ for the lateral load resisting system adopted (IS: 1893 Table 7), and take $\mathrm{Sa} / \mathrm{g}$ for the computed time period values

(c) Calculate the total horizontal shear (the base shear)

The design value of base shear $V_{B}$

$\mathrm{V}_{\mathrm{B}}=\mathrm{A}_{\mathrm{h}} \mathrm{W}$
As per IS 1893 Cl.7.5.3.

(d) Seismic Moments and Forces in Frame Elements: Calculate the seismic moments and axial forces in the columns, shears and moments in the beams by using the seismic weights on the floors/ (column beam joints) through an appropriate computer software (having facility for using floors as rigid diaphragm and torsional effects as per IS: 1893:2002).

Table -3: Seismic force on each floor

\begin{tabular}{|l|l|l|}
\hline FLOORS & HEIGHT $\mathbf{~}$ & $\mathbf{Q}_{\mathbf{i}} \mathbf{k N}$ \\
\hline 1 & 3 & 7 \\
\hline 2 & 6 & 28 \\
\hline 3 & 9 & 62 \\
\hline 4 & 12 & 110 \\
\hline 5 & 15 & 172 \\
\hline 6 & 18 & 248 \\
\hline 7 & 21 & 338 \\
\hline 8 & 24 & 441 \\
\hline \multicolumn{2}{|l}{ TOTAL } & 1406 \\
\hline
\end{tabular}

\subsection{Design for Shear}

Members Subjected to Shear: Reinforced masonry walls may be designed taking contribution of shear reinforcement.

Where contribution of shear reinforcement is considered in resisting shear force the minimum area of shear reinforcement in the direction of force shall be determined by the following:

$$
\mathrm{A}_{\mathrm{v} \min }=\mathrm{V}_{\mathrm{S}} / \mathrm{F}_{\mathrm{S}} \mathrm{d}
$$

$\mathrm{V}=$ total applied shear force

$\mathrm{S}=$ spacing of the shear reinforcement

$\mathrm{d}=$ distance from extreme compression fiber to centroid of tension reinforcement

$\mathrm{Fs}=$ permissible stress in steel reinforcement

\subsection{Location of the Center of Mass}

\begin{tabular}{|c|c|c|c|c|c|c|c|c|c|}
\hline $\begin{array}{c}\text { Par } \\
\mathrm{t}\end{array}$ & $\begin{array}{l}\mathrm{B} \\
\mathrm{m}\end{array}$ & $\begin{array}{l}\mathrm{D} \\
\mathrm{m}\end{array}$ & $\begin{array}{c}\text { ARE } \\
\text { A } \\
\mathrm{m}^{2}\end{array}$ & $X$ & $\mathrm{AX}$ & Y & AY & $\begin{array}{l}X^{\prime} \\
m\end{array}$ & $\begin{array}{l}Y^{\prime} \\
\mathrm{m}\end{array}$ \\
\hline al & $\begin{array}{c}3 . \\
4\end{array}$ & $\begin{array}{l}1 . \\
0\end{array}$ & 3.4 & 7.3 & 24.8 & ${ }^{-} .5$ & -1.7 & \multirow{4}{*}{$\begin{array}{l}7 . \\
0\end{array}$} & \multirow{4}{*}{$\begin{array}{c}11 . \\
7\end{array}$} \\
\hline a2 & 12 & $\begin{array}{l}8 . \\
4\end{array}$ & 101.3 & 6.0 & 607 & 4.2 & $\begin{array}{c}425 . \\
4\end{array}$ & & \\
\hline a3 & $\begin{array}{l}4 . \\
7\end{array}$ & $\begin{array}{l}5 . \\
4 \\
\end{array}$ & 25.7 & $\begin{array}{c}11 . \\
5\end{array}$ & 296 & $\begin{array}{c}11 . \\
0\end{array}$ & $\begin{array}{c}284 . \\
2\end{array}$ & & \\
\hline $\mathrm{a} 4$ & 12 & $\begin{array}{l}8 . \\
4 \\
\end{array}$ & 101.3 & 6.0 & 607 & $\begin{array}{c}19 . \\
5 \\
\end{array}$ & $\begin{array}{c}197 \\
5 \\
\end{array}$ & & \\
\hline
\end{tabular}

Table -4: Centre of mass calculation 


\begin{tabular}{|c|c|c|c|c|c|c|c|l|l|}
\hline a5 & $\begin{array}{c}3 . \\
4\end{array}$ & $\begin{array}{c}1 . \\
0\end{array}$ & 3.4 & $\begin{array}{c}7.3 \\
2\end{array}$ & 24.8 & $\begin{array}{c}22 . \\
3\end{array}$ & 75.8 & & \\
\hline \multicolumn{3}{|c|}{ TOTAL } & 252 & & $\begin{array}{c}177 \\
2\end{array}$ & & $\begin{array}{c}295 \\
8\end{array}$ & & \\
\hline
\end{tabular}

\subsection{Location of the Center of Stiffness}

Provision shall be made in all buildings for increase in shear forces on the lateral force resisting elements resulting from the horizontal torsional moment arising due between the centres of mass. And centre of rigidity. The design forces calculated as in IS 1893 Part 1 clause. 7.8.4.5 Are. To be applied at the centre of mass appropriately displaced so as to cause design eccentricity (IS 1893 Part 1 clause 7.9.2) between the displaced centre of mass and centre of rigidity. However, negative torsional shear shall be neglected.

Table -5: Center of Stiffness

\begin{tabular}{|l|l|l|l|l|l|l|}
\hline PIER & $\mathrm{X}$ & $\mathrm{Y}$ & $\mathrm{K}_{\mathrm{X}}$ & $\mathrm{K}_{\mathrm{Y}}$ & $\mathrm{K}_{\mathrm{X}} \mathrm{Y}$ & $\mathrm{K}_{\mathrm{Y}}$ \\
\hline 1 & 1.23 & 0.1 & $4.0 \mathrm{E}+07$ & $6.9 \mathrm{E}+05$ & $4.0 \mathrm{E}+06$ & $8.5 \mathrm{E}+05$ \\
\hline 2 & 4.24 & 0.1 & $3.8 \mathrm{E}+05$ & $1.1 \mathrm{E}+05$ & $3.8 \mathrm{E}+04$ & $4.7 \mathrm{E}+05$ \\
\hline 3 & 5.48 & 0.1 & $3.8 \mathrm{E}+05$ & $1.1 \mathrm{E}+05$ & $3.8 \mathrm{E}+04$ & $6.0 \mathrm{E}+05$ \\
\hline 5 & 5.82 & -0.5 & $5.9 \mathrm{E}+06$ & $2.9 \mathrm{E}+05$ & $-2.9 \mathrm{E}+06$ & $1.7 \mathrm{E}+06$ \\
\hline 6 & 6.47 & -1.2 & $5.9 \mathrm{E}+06$ & $2.9 \mathrm{E}+05$ & $-7.1 \mathrm{E}+06$ & $1.9 \mathrm{E}+06$ \\
\hline 8 & 8.79 & -1.2 & $2.7 \mathrm{E}+06$ & $2.2 \mathrm{E}+05$ & $-3.3 \mathrm{E}+06$ & $1.9 \mathrm{E}+06$ \\
\hline 9 & 9.44 & -0.5 & $2.7 \mathrm{E}+06$ & $2.2 \mathrm{E}+05$ & $-1.4 \mathrm{E}+06$ & $2.1 \mathrm{E}+06$ \\
\hline 10 & 9.98 & 0.1 & $1.1 \mathrm{E}+06$ & $8.2 \mathrm{E}+07$ & $1.1 \mathrm{E}+05$ & $8.2 \mathrm{E}+08$ \\
\hline 11 & 13.65 & 0.1 & $2.7 \mathrm{E}+05$ & $4.7 \mathrm{E}+06$ & $2.7 \mathrm{E}+04$ & $6.4 \mathrm{E}+07$ \\
\hline
\end{tabular}

\subsection{Stress in Steel}

Table -6: Stress in steel

\begin{tabular}{|c|c|c|c|c|}
\hline PIER NO & $\begin{array}{c}\text { FC } \\
\text { MPa }\end{array}$ & $\begin{array}{c}\text { NET COMPRESSION } \\
\text { MPa }\end{array}$ & $\begin{array}{c}\text { TOTAL } \\
\text { MPa }\end{array}$ & $\begin{array}{c}\text { STRESS IN STEEL } \\
\text { MPa }\end{array}$ \\
\hline 1 & 1.59 & 2.022 & 3.613 & 253.99 \\
\hline 2 & 0.02 & 2.174 & 2.190 & 0.93 \\
\hline 3 & 0.02 & 2.174 & 2.190 & 0.93 \\
\hline 4 & 0.31 & 2.095 & 2.401 & 31.13 \\
\hline 5 & 0.31 & 2.095 & 2.401 & 31.13 \\
\hline 7 & 0.14 & 2.755 & 2.891 & 11.94 \\
\hline 8 & 0.14 & 2.755 & 2.891 & 11.94 \\
\hline 9 & 0.01 & 2.162 & 2.168 & 1.38 \\
\hline 10 & 0.00 & 2.755 & 2.758 & 0.35 \\
\hline
\end{tabular}




\subsection{Allowable Shear Stress}

Table -7: Allowable Shear Stress

\begin{tabular}{|c|c|c|c|c|c|c|c|c|}
\hline $\begin{array}{c}\text { Pier } \\
\text { no }\end{array}$ & $\begin{array}{c}\text { SHEAR } \\
\text { FORCE }\end{array}$ & $\mathrm{d}$ & $\mathrm{B}$ & $\begin{array}{c}\text { SHEAR } \\
\text { STRESS }\end{array}$ & $\begin{array}{c}\text { BENDIG } \\
\text { MOMENT }\end{array}$ & $\begin{array}{c}\text { ALLOWABLE } \\
\text { SHEAR STRESS }\end{array}$ & $\begin{array}{c}\text { MAX ALLOWBLE } \\
\text { SHEAR STRESS }\end{array}$ \\
\hline & $\mathrm{N} / \mathrm{mm}^{2}$ & $\mathrm{~m}$ & $\mathrm{~m}$ & $\mathrm{~N} / \mathrm{mm}^{2}$ & $\mathrm{~N} / \mathrm{mm}^{2}$ & & $\mathrm{~N} / \mathrm{mm}^{2}$ & $\mathrm{~N} / \mathrm{mm}^{2}$ \\
\hline 1 & $3.42 \mathrm{E}+01$ & $2.35 \mathrm{E}+03$ & 200 & 0.073 & $3.84 \mathrm{E}+01$ & 0.47 & 0.22 & 0.17 \\
\hline 2 & $7.13 \mathrm{E}-01$ & $3.75 \mathrm{E}+02$ & 200 & 0.010 & $8.02 \mathrm{E}-01$ & 3.00 & 0.23 & 0.2 \\
\hline 3 & $7.13 \mathrm{E}-01$ & $3.75 \mathrm{E}+02$ & 200 & 0.010 & $8.02 \mathrm{E}-01$ & 3.00 & 0.23 & 0.2 \\
\hline 4 & $9.31 \mathrm{E}+00$ & $1.00 \mathrm{E}+03$ & 200 & 0.047 & $1.05 \mathrm{E}+01$ & 1.12 & 0.23 & 0.2 \\
\hline 5 & $9.35 \mathrm{E}+00$ & $1.00 \mathrm{E}+03$ & 200 & 0.047 & $1.05 \mathrm{E}+01$ & 1.12 & 0.23 & 0.2 \\
\hline 6 & $4.73 \mathrm{E}+00$ & $7.50 \mathrm{E}+02$ & 200 & 0.032 & $5.32 \mathrm{E}+00$ & 1.50 & 0.23 & 0.2 \\
\hline 7 & $4.71 \mathrm{E}+00$ & $7.50 \mathrm{E}+02$ & 200 & 0.031 & $5.30 \mathrm{E}+00$ & 1.50 & 0.23 & 0.2 \\
\hline 8 & $2.07 \mathrm{E}+00$ & $2.00 \mathrm{E}+02$ & 3650 & 0.003 & $2.33 \mathrm{E}+00$ & 5.62 & 0.23 & 0.2 \\
\hline 9 & $5.20 \mathrm{E}-01$ & $2.00 \mathrm{E}+02$ & 915 & 0.003 & $5.85 \mathrm{E}-01$ & 5.62 & 0.23 & 0.23 \\
\hline 10 & $5.16 \mathrm{E}-01$ & $2.00 \mathrm{E}+02$ & 915 & 0.003 & $5.81 \mathrm{E}-01$ & 5.62 & & \\
\hline
\end{tabular}

\subsection{Shear and Bending Force}

Table -8: Shear and Bending Force

\begin{tabular}{|c|c|c|c|c|c|c|}
\hline \multirow{2}{*}{ PIER NO } & \multicolumn{2}{|c|}{ Force in each pier } & \multicolumn{2}{|c|}{ Along X IN kN } & \multicolumn{2}{|c|}{ Along Y IN kN } \\
\hline & Along $\mathrm{X} \mathrm{kN}$ & Along $\mathrm{Y} \mathrm{kN}$ & Shear force & Bending force & Shear force & Bending force \\
\hline 1 & $7.49 \mathrm{E}+01$ & $1.53 \mathrm{E}+00$ & $3.11 \mathrm{E}+01$ & $4.39 \mathrm{E}+01$ & $1.51 \mathrm{E}+00$ & $1.55 \mathrm{E}-02$ \\
\hline 2 & 7.09E-01 & $2.44 \mathrm{E}-01$ & $6.84 \mathrm{E}-01$ & $2.46 \mathrm{E}-02$ & $2.42 \mathrm{E}-01$ & $2.47 \mathrm{E}-03$ \\
\hline 3 & 7.09E-01 & $2.44 \mathrm{E}-01$ & $6.84 \mathrm{E}-01$ & $2.46 \mathrm{E}-02$ & $2.42 \mathrm{E}-01$ & $2.47 \mathrm{E}-03$ \\
\hline 5 & $1.11 \mathrm{E}+01$ & $6.51 \mathrm{E}-01$ & $8.83 \mathrm{E}+00$ & $2.26 \mathrm{E}+00$ & $6.44 \mathrm{E}-01$ & $6.59 \mathrm{E}-03$ \\
\hline 6 & $1.11 \mathrm{E}+01$ & $6.51 \mathrm{E}-01$ & $8.83 \mathrm{E}+00$ & $2.26 \mathrm{E}+00$ & $6.44 \mathrm{E}-01$ & $6.59 \mathrm{E}-03$ \\
\hline 8 & $5.14 \mathrm{E}+00$ & $4.88 \mathrm{E}-01$ & $4.49 \mathrm{E}+00$ & $6.45 \mathrm{E}-01$ & $4.83 \mathrm{E}-01$ & $4.94 \mathrm{E}-03$ \\
\hline 9 & $5.14 \mathrm{E}+00$ & $4.88 \mathrm{E}-01$ & $4.49 \mathrm{E}+00$ & $6.45 \mathrm{E}-01$ & $4.83 \mathrm{E}-01$ & 4.94E-03 \\
\hline 10 & $2.01 \mathrm{E}+00$ & $1.82 \mathrm{E}+02$ & $1.99 \mathrm{E}+00$ & $2.04 \mathrm{E}-02$ & $4.12 \mathrm{E}+01$ & $1.40 \mathrm{E}+02$ \\
\hline
\end{tabular}

\section{REINFORCEMENT DETAILING}

From the design we came to know that the nominal reinforcement is enough to ensure flexural stiffness of the building. But to ensure shear force the web reinforcement has to be provided at every bed joint.

\section{Minimum Reinforcement Requirements}

Vertical reinforcement of at least $100 \mathrm{~mm}^{2}$ in cross-sectional area shall be provided at a maximum spacing of $3 \mathrm{~m}$ on centre at critical sections:

a) Corners

b) Within $400 \mathrm{~mm}$ of each side of openings, c) Within $200 \mathrm{~mm}$ of the end of the walls

Reinforcement around openings need not be provided for opening smaller than $400 \mathrm{~mm}$ in either direction. The masonry shall be uniformly reinforced in both horizontal and vertical direction such that the sum of reinforcement area in both directions shall be at least $0.2 \%$ of the gross crosssectional area of the wall and minimum reinforcement area in each direction shall be not less than $0.07 \%$ of the gross crosssectional area of the wall. Reinforcement around openings need not be provided for opening smaller than $400 \mathrm{~mm}$ in either direction. Horizontal reinforcement shall consist of at least two bars of $6 \mathrm{~mm}$ spaced not more than $400 \mathrm{~mm}$; or bond 
beam reinforcement shall be provided of at least $100 \mathrm{~mm}^{2}$ in cross-sectional area spaced not more than $3 \mathrm{~m}$. Horizontal reinforcement shall be provided at the bottom and top of wall openings and shall extend at least $500 \mathrm{~mm}$ or 40 bar diameters past the openings; continuously at structurally connected roof and floor levels and within $400 \mathrm{~mm}$ of the top of the walls.

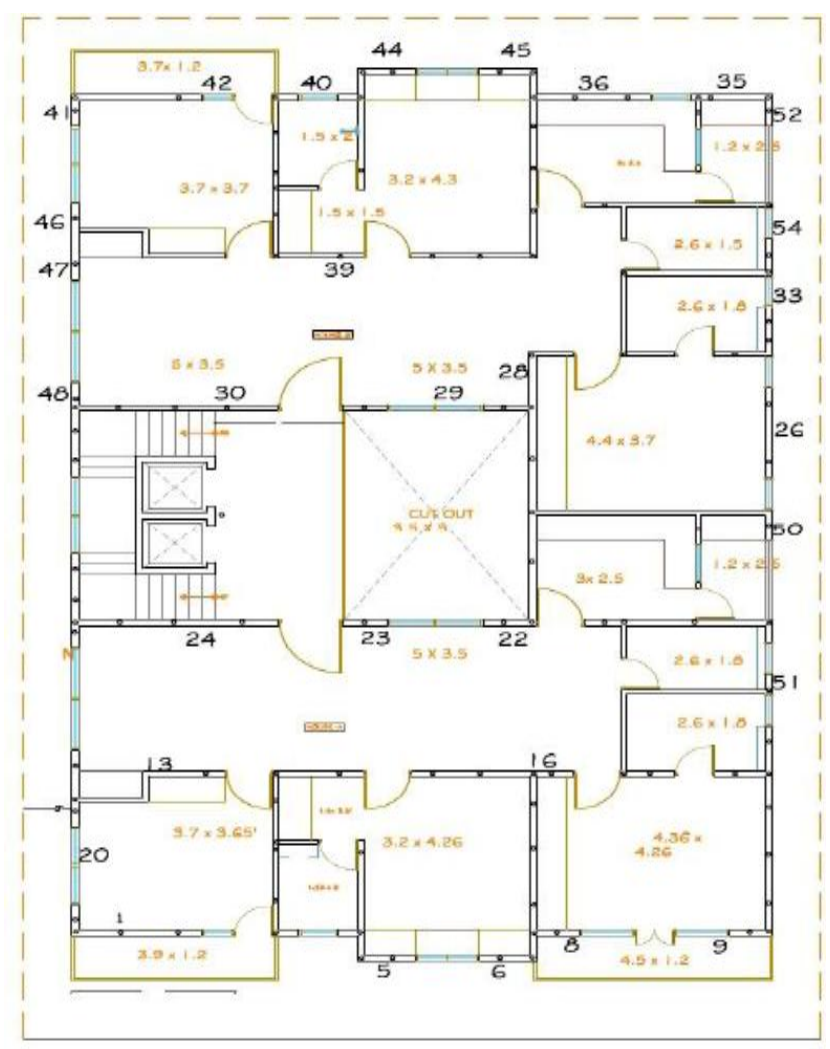

Fig-3 Reinforcement details

\section{DESIGN OF RCC FRAME}

The procedure for analysis and design of a given building will depend on the type of building, its complexity, the number of stories etc. First the architectural drawings of the building are studied, structural system is finalized sizes of structural members are decided and brought to the knowledge of the concerned architect. The procedure for structural design will involve some steps which will depend on the type of building and also its complexity and the time available for structural design. The principle objective of this project is to analyse and design a multi-storeyed building [ $\mathrm{G}+8$ (3 dimensional frame)] using STAAD.Pro. The design involves load calculations manually and analysing the whole structure by STAAD Pro. The design methods used in STAAD-Pro analysis are Limit State Design conforming to Indian Standard Code of Practice

\section{COMPARISION BETWEEN RHCBM AND RC FRAMED STRUCTURE}

Design parameter for the comparison purpose: 3 main parameters of the building considered, viz steel concrete and blocks. The slab quantities are almost same for the both type of the building hence it is neglected in comparison. The total quantities of steel and concrete of the RC framed building is obtained directly from the Staad,Pro software.

Table -9: Comparison between Rhcbm and Rc Framed Structure

\begin{tabular}{|l|l|l|l|}
\hline & MATERIAL & RHCBM & $\begin{array}{l}\text { RC } \\
\text { FRAME }\end{array}$ \\
\hline 1 & Steel & 3 tones & 30 tones \\
\hline 2 & BLOCKS in number & 40000 & 40000 \\
\hline 3 & $\begin{array}{l}\text { CONCRETE only } \\
\text { for grout filling }\end{array}$ & $45 \mathrm{~m}^{3}$ & $170 \mathrm{~m}^{3}$ \\
\hline
\end{tabular}

\section{CONCLUSIONS}

\subsection{Concluding Remarks}

Multistoried load bearing masonry building in India is emerging only recently. Indeed there are hardly any examples of reinforced masonry system building, despite masonry possessing good many advantages. In this project the analysis and design of reinforced hollow concrete block masonry as a load bearing member for $\mathrm{G}+8$ storied residential apartments has been presented comprehensively. The design itself has been carried out for all the combination of load which includes vertical and lateral loads. Nominal masonry strength of 7.5MPa has been chosen for the design. While the walls designed for axial and eccentric loads as per IS 1907-1987 and draft code of reinforced masonry, the lateral loads design have been carried out as per the accepted structural analysis principles.

Based on the analysis and design the following broad set of conclusion can be drawn.

1) It was found that masonry strength of $7.5 \mathrm{MPa}$ with $\mathrm{H} 1$ grade mortar is sufficient for the vertical/eccentric loads for almost all the walls. Only 2 out of 34 walls needed a nominal vertical reinforcement.

2) It was noticed that for the typical building plan chosen in Bangalore the earthquake loads are marginally higher than winds for $\mathrm{G}+8$ configurations. Hence the lateral load design of wall based on critical combination of DL, LL and EL.

3 ). Since, the analysis and design calculations are quite involved, a series of spread sheet were developed to identify the crucial design parameter for each wall of the building. The spread sheet includes: 
a) Design for axial and eccentric load for all the walls;

b) Obtaining lateral stiffness and relative stiffness of all the walls;

c) Analysis and design for flexure and shear.

d) Analysis for all combination for axial and lateral loads.

e) Analysis for including the effect of torsion.

4) Based on the analysis and design it was found that lateral load combination along shorter dimension of the building was more critical. This is to be expected because of relatively lesser lateral stiffness along this direction. However the criticality depends on the configuration of load bearing wall. it is suggested that as for as possible there has to adequate amount of stiffness along the considered critical lateral load direction.

5) It was found that the flexure stresses were within the permissible limit and hence nominal reinforcement is adequate.

6) The shear stress exceeded allowable stress limits for significant numbers of wall. Therefore the design needed provision of web reinforcement. This web reinforcement is suggested at every bed joint of masonry element.

7) The same building was design as a conventional RC framed structure. The analysis and design carried out by using structural analysis software. By comparing the material required for the both building approximately it is noticed that the load bearing masonry structure is significantly more economical than $\mathrm{RC}$ framed structure.

\section{ACKNOWLEDGEMENTS}

I would like to thank my mentor and guide Dr. Raghunath $\mathrm{S}$, Professor, Department of Civil Engineering, BMSCE, Bengaluru, for his constant encouragement, guidance and support, which enabled me to complete this project.

I would like to thank my Parents and friends for their encouragement and support.

\section{REFERENCES}

[1]. Narendra Taly (2010), DESIGN OF REINFORCED MASONRY STRUCTURE S, Second Edition New McGrawHill New York, Professor Emeritus Department of Civil Engineering California State University, Los Angeles.

[2]. A.W. Hendry (2004), "DESIGN OF MASONRY STRUCTURES" Third edition of Load Bearing Brickwork, Published by E \& FN Spon, an imprint of Chapman \& Hall, 2-6 Boundary Row, London SE1 8HN, UK .

[3]. MASONRY STRUCTURAL DESIGN FOR BUILDINGS - DEPARTMENTS OF THE ARMY, THE NAVY, AND THE AIR FORCE WASHINGTON, DC, 30 October 1992.

[4]. "REINFORCED MASONRY" Lecture notes of Dr. S Raghunath, Professor, Department of Civil Engineering, BMSCE, Bangalore.

[5]. EUROCODE 6: Design of masonry structures EN 1996-11 General- Rules for reinforced and unreinforced masonry.
[6]. K.S. Nanjunda Rao, "STRUCTURAL MASONRY: PROPERTIES AND BEHAVIOUR", Department of Civil Engineering, Indian Institute of Science, Bangalore.

[7]. IITK-GSDMA GUIDELINES for STRUCTURAL USE of REINFORCED MASONRY, Dr. Durgesh C Rai Department of Civil Engineering Indian Institute of technology Kanpur.

[8]. Structural Use of Unreinforced Masonry by Dr. Durgesh C. Rai, Department of Civil Engineering, Indian Institute of Technology, Kanpur.

[9]. Structural Masonry Designers' Manual- W. G. Curtin, G. Shaw, J. K. Beck and W. A. Bray, Third Edition revised by David Easterbrook Blackwell.

\section{BIOGRAPHIES}

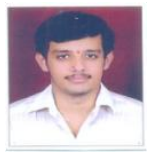

Mr. Shashank B S studied at one of the esteemed college BMSCE BANGALORE and working in THE OXFORD College of Engineering Bangalore as a Assistant Professor.

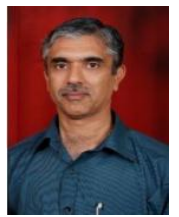

Dr. S. RAGHUNATH, Professor at the BMSCE Bangalore in Department of Civil Engineering with more than 25 year of experience. Published about 30 papers in National and International journals and supervised more than $40 \mathrm{PG}$ project works 